\title{
Frequency of $\mathrm{B}$-Thalassemia Trait among Pregnant Women Presenting at Pakistan Institute of Medical Sciences
}

\author{
Asma Mustafa*, Maryam Zulfiqar, Bushra Anam Ali, Lubna Naseem \\ Pakistan Institute of Medical Sciences, Islamabad, Pakistan.
}

\begin{abstract}
Introduction: Thalassemia is a common inherited disorder in Pakistan with around 5000 new cases diagnosed every year. Despite various preventive measures taken at the national level, the disease burden is still not declining. In this study the incidence of $\beta$ Thalassemia trait among pregnant females presenting to a tertiary care hospital is measured.
\end{abstract}

Methods: This study was conducted at Pakistan Institute of Medical sciences. 102 Pregnant females who were referred to us for hemoglobin electrophoresis from July 2017-June 2018 were included. Complete blood count, peripheral film, reticulocyte count and hemoglobin electrophoresis was performed for each patient.

Results: The mean age was 25 years and the mean period of gestation was 30.30 weeks. Out of 102 patients, 5 (4.9\%) were diagnosed as $\beta$ Thalassemia trait. Of these, $2(40 \%)$ did not have a positive family history of Thalassemia. We compared the results of our study with those done at different regions of Pakistan and found variable incidence of carrier state in different regions of the country.

Conclusion: Antenatal screening is a forward step towards minimizing incidence of Thalassemia in Pakistan however clinicians should be directed to refer these patients in early pregnancy.

Keywords: $ß$-Thalassemia, Thalassemia trait, Antenatal screening, Anemia, Iron deficiency, Thalassemia prevention.

\section{INTRODUCTION}

B Thalassemia is an inherited genetic disorder resulting in defective hemoglobin synthesis. The heterozygous state is called Thalassemia trait while the homozygous state is called Thalassemia major. Individuals suffering from later require lifelong blood transfusions. They eventually go into iron overload causing multi organ damage. This increases the morbidity and mortality rate of these patients.

Thalassemia is prevalent worldwide. It is estimated that around $3 \%$ of the whole world population carries the mutation for Thalassemia. Each year 60,000 babies are born with Thalassemia of which $80 \%$ burden is mainly on the Asian countries [1]. In Pakistan, 5000 cases are diagnosed with Thalassemia every year. The carrier rate in our country is $5-8 \%[2,3]$.

The antenatal screening of Thalassemia has effectively reduced the incidence of Thalassemia in Taiwan. After seven years, the incidence of Thalassemia decreased from 20 cases per year to 3. Similar program was run in Guangdong province of China for 11 years. In many other countries of the world, such as Cyprus, Greece, Italy, Bahrain, India, Iran, Saudi Arabia, United Arab Emirates, Malaysia, Indonesia, Maldives, Singapore, Thailand and United Kingdom prenatal Thalassemia diagnosis is being practiced [4].

In Pakistan, Punjab Thalassemia Prevention Program (PTPP)

*Address correspondence to this author at the Pakistan Institute of Medical Sciences, Islamabad, Pakistan.

E-mail: asmamustafa87@gmail.com has also taken several steps to minimize the incidence of the disease. Among these, antenatal screening of pregnant females has been initiated. We therefore analyzed the data of all pregnant females who presented to our tertiary care hospital.

\section{MATERIALS AND METHODS}

A cross sectional study was conducted at Pathology department of Pakistan Institute of Medical Sciences (PIMS) from July 2017 till June 2018. All pregnant women who were referred to us for hemoglobin electrophoresis were included in the study. Complete history was taken from the patients regarding their symptoms, comorbids, parity, and consanguinity of marriage, previous history of Thalassemia in family and current use of medications. Patients who had recent history of transfusion were deferred.

Complete blood count, reticulocyte count and peripheral smear were also prepared in addition to hemoglobin electrophoresis.

\section{RESULTS}

A total of 102 pregnant women were included in the study. The average age was 25 years (18-39 years). The average period of gestation at which they presented to us was 30.30 weeks (10-40 weeks). All patients had symptomatic pallor and anemia (Table 1). Two patients had a history of pregnancy induced hypertension (PIH), two had previous miscarriages and one patient had a twin pregnancy. 65 $(63.7 \%)$ patients were primary gravida while the remaining 37 
(36.4\%) were multiparous. Only 8 (7.8\%) patients gave a positive family history of $\beta$ Thalassemia in first and second degree relatives. $35(34.3 \%)$ patients were product of consanguineous marriage. The results are tabulated in Table 2.

Out of 102 patients, 5 (4.9\%) were diagnosed as $\beta$ Thalassemia trait, 38 (37.2\%) had normal electrophoresis but peripheral film and reticulocyte count were suggestive of severe iron deficiency. These included microcytic hypochromic picture with pencil cells and target cells. The remaining 59 (57.8\%) were normal results (Table 3). Only 21 $(20.5 \%)$ patients were taking antenatal supplements which included iron complex, folic acid, calcium and multivitamin complex.

Among the 5 patients who were diagnosed as $\beta$ Thalassemia trait, only $3(60 \%)$ had a positive family history of Thalassemia as shown in Table 4.

Table 1. Shows Complete Blood Picture Findings.

\begin{tabular}{|c|l|c|c|}
\hline \multicolumn{2}{|l|}{ Parameters } & Mean \pm SD & Range (min-max) \\
\hline 1 & Age (Years) & $25 \pm 4.4$ & $18-39$ \\
\hline 2 & Period of Gestation (weeks) & $30.30 \pm 6.05$ & $4.6-18.6$ \\
\hline 3 & Total Leucocyte Count $\left(\times 10^{3} / \mu \mathrm{L}\right)$ & $9.63 \pm 2.15$ & $2.62-5.53$ \\
\hline 4 & Erythrocyte Count $\left(\times 10^{6} / \mu \mathrm{L}\right)$ & $3.96 \pm 0.57$ & $4.0-12.6$ \\
\hline 5 & Hemoglobin $(\mathrm{g} / \mathrm{dL})$ & $8.98 \pm 1.5$ & $23-49$ \\
\hline 6 & Hematocrit $(\%)$ & $37 \pm 4.8$ & $49.5-109$ \\
\hline 7 & Mean Corpuscular Volume (fL) & $75.2 \pm 9.7$ & $13.4-34$ \\
\hline 8 & Mean Corpuscular Hemoglobin $(\mathrm{pg})$ & $23 \pm 4.06$ & $20.8-35$ \\
\hline 9 & Mean Corpuscular Hemoglobin & $30.08 \pm 2.3$ & $150-560$ \\
\hline 10 & Concentration (g/dL) & & $38-86$ \\
\hline 11 & Dlatelet Count $\left(\times 10^{3} / \mu \mathrm{L}\right)$ & $297 \pm 80$ & $11-54$ \\
\hline & 2. Neutrophil (\%) & $70.92 \pm 8.9$ & $0-18$ \\
\hline & 2. Lymphocyte (\%) $\%$ Monocyte $(\%)$ & $23.1 \pm 7.8$ & $0-16$ \\
\hline & 4. Eosinophil (\%) & $4.08 \pm 3$ & $0.3-7.4$ \\
\hline 12 & Reticulocyte Count (\%) & $2.1 \pm 2$ & \\
\hline
\end{tabular}

Table 2. Shows Details of the Clinical History and Result of Hemoglobin Electrophoresis.

\begin{tabular}{|c|l|c|c|}
\hline \multicolumn{2}{|c|}{ Parameters } & $<20$ years & No (\%) \\
\hline 1 & Age & $20-30$ years & $6.7 \%$ \\
& & $31-40$ years & $82.3 \%$ \\
& & $<20$ weeks & $11.0 \%$ \\
\hline 2 & Period Of Gestation & $20-30$ weeks & $4.9 \%$ \\
& & $>31$ weeks & $50.9 \%$ \\
& & Primary Gravida & $44.2 \%$ \\
\hline 3 & Parity & Multiparous & $65(63.7)$ \\
& & Positive & $37(36.4)$ \\
\hline 4 & Family History of Thalassemia & Negative & $8(7.8)$ \\
& & Positive & $94(92.2)$ \\
\hline 5 & Consanguity & Negative & $35(37.2)$ \\
& & Yes & $67(62.8)$ \\
\hline 6 & Antenatal Supplements & No & $21(20.5)$ \\
& & & $81(79.5)$ \\
\hline
\end{tabular}


Table 3. Hemoglobin Electrophoresis Pattern.

\begin{tabular}{|c|c|c|}
\hline Electrophoresis Pattern & Normal & $107(95.1)$ \\
\hline & Trait & $5(4.9)$ \\
\hline
\end{tabular}

Table 4. The Details of 5 Thalassemia Trait Patients is Given Below.

\begin{tabular}{|c|c|c|c|c|c|}
\hline $\begin{array}{c}\text { Patient } \\
\text { no. }\end{array}$ & Age (year) & $\begin{array}{c}\text { Period of Gestation } \\
\text { (weeks) }\end{array}$ & Parity & Comorbids & $\begin{array}{c}\text { Family History } \\
\text { of Thalassemia }\end{array}$ \\
\hline 1 & 23 & 21 & Multigravida & Hypertension & Positive \\
\hline 2 & 20 & 39 & Primary gravida & Nil & Negative \\
\hline 3 & 23 & 34 & Primary gravida & Nil & Positive \\
\hline 4 & 23 & 31 & Multigravida & Nil & Negative \\
\hline 5 & 25 & 14 & Multigravida & Nil & Positive \\
\hline
\end{tabular}

\section{DISCUSSION}

Our study showed that the incidence of $\beta$-Thalassemia trait was $4.9 \%$. Although this is a small number when compared to the frequencies mentioned in other ante natal screening studies. The alarming sign in our study was that out of these 5 patients, 2 of them did not have a positive family history of Thalassemia. They had the carrier genes in the family but none of the family members were aware or had their Hemoglobin electrophoresis been done.

The results of our study were similar to those observed by Khan, et al. who reported presence of $\beta$ Thalassemia trait in $3.2 \%$ of the cases $(\mathrm{n}=56)$. However hemoglobin electrophoresis was performed in only 7 cases that had erythrocyte count i.e $>4600000 / \mathrm{cmm}^{3}$ [5]. Similarly Nisa, et al. found $8.7 \%(\mathrm{n}=200)$ of the patients to be carrier out of which $59 \%$ had first cousin marriage and $24 \%$ had a positive family history for thalassemia [6]. A slightly higher frequency was stated by Lone, et al. who found $18.41 \%(\mathrm{n}=315)$ pregnant women to be positive for Thalassemia trait [7].

Qadir and Amir evaluated 194 pregnant women who presented to the gynecology and obstetrics Unit of Khyber teaching hospital, Peshawar. $56.7 \%$ of the patients were diagnosed $\beta$ Thalassemia trait. This number is quite high compared to our study [8].

Hafiz M, et al. conducted a study in Lahore and also found $53.1 \%$ of the patients to be $\beta$-Thalassemia trait [9].

Table 5. A Comparison of Our and Other Local Studies is Given Below.

\begin{tabular}{|c|c|c|c|c|c|c|}
\hline $\begin{array}{c}\text { Study } \\
\text { (Year) }\end{array}$ & Place of Study & Population & Sample Size & $\begin{array}{c}\text { Thalassemia } \\
\text { Trait (\%) }\end{array}$ & $\begin{array}{c}\text { Family History } \\
\text { (\%) }\end{array}$ & $\begin{array}{c}\text { Consanguity of } \\
\text { Marriage (\%) }\end{array}$ \\
\hline $\begin{array}{c}\text { Our Study } \\
(2018)\end{array}$ & $\begin{array}{c}\text { PIMS, } \\
\text { Islamabad }\end{array}$ & $\begin{array}{c}\text { Pregnant } \\
\text { females }\end{array}$ & 102 & 4.9 & 7.8 & 34.3 \\
\hline $\begin{array}{c}\text { Khan } \text { et al. } \\
(2017)\end{array}$ & $\begin{array}{c}\text { PGMI, } \\
\text { Peshawar }\end{array}$ & $\begin{array}{c}\text { Pregnant } \\
\text { females }\end{array}$ & 56 & 3.5 & - & - \\
\hline $\begin{array}{c}\text { Qadir and } \\
\text { Amir (2017) }\end{array}$ & $\begin{array}{c}\text { KTH, } \\
\text { Peshawar }\end{array}$ & $\begin{array}{c}\text { Pregnant } \\
\text { females }\end{array}$ & 194 & 56.7 & - & - \\
\hline $\begin{array}{c}\text { Lone } \text { et al. } \\
(2017)\end{array}$ & $\begin{array}{c}\text { UHS, } \\
\text { Lahore }\end{array}$ & $\begin{array}{c}\text { Females of } \\
\text { reproductive age }\end{array}$ & 315 & 18.41 & - & - \\
\hline $\begin{array}{c}\text { Nisa, } \text { et al. } \\
(2011)\end{array}$ & $\begin{array}{c}\text { Liaqat } \\
\text { University } \\
\text { hospital, } \\
\text { Hyderabad }\end{array}$ & $\begin{array}{c}\text { Pregnant } \\
\text { females }\end{array}$ & 200 & 8.5 & 24 & 59 \\
\hline
\end{tabular}

Table 5 shows the tabulated form of comparison between studies done in our local population. The differences in the results of our and other local population studies could be explained with the consanguinity of marriages and knowledge of Thalassemia. It is also quite possible that Thalassemia carrier state is more prevalent in those areas of Pakistan.
Other studies done in other Asian region countries also found a higher incidence of $\beta$ Thalassemia trait. According to Sinha, et al. $50 \%(\mathrm{n}=120)$ of the patients were $\beta$ Thalassemia trait in an Indian province [10]. Similarly, Mohanty D, et al. found $55.9 \%$ of the pregnant females to be carriers of the disease [11]. 
Baxi, et al. found only $2.78 \%$ of pregnant women $(\mathrm{n}=1006)$ to be the carrier in Indore, India [12]. Wanapirak, et al. found $25.4 \%$ of the pregnant females to be the carriers of Thalassemia [13]. Similarly, Sarda H, et al. found $51.6 \%$ of the anemic pregnant females to be the carrier [14]. The variable values is suggestive of uneven distribution of the carrier state in different regions of the country.

It is also recommended that antenatal screening should be done before 11 weeks of gestation and screening of the partner should be completed by 12 weeks of pregnancy [15]. However, in our study the mean period of gestation at which the females were referred was 30.30 weeks. A report by Haq, et al. stated that $92 \%$ of the parents with cousin marriage had no knowledge of Thalassemia before their Thalassemic child [16]. Therefore, if antenatal screening of the couple is done in early pregnancy, they can be counseled about the termination of pregnancy if Chorionic villous sampling showing Thalassemia Major fetus.

\section{CONCLUSION}

Antenatal Thalassemia screening is an effective step towards reducing the incidence of Thalassemia in our population. Considering the low literacy rate of our population, it is essential to include such screening programs in the legislation. The financial burden imposed on families of Thalassemia sufferers is far greater than early detection of the carrier state. Moreover, it is essential that clinicians know the ideal time for the screening of Thalassemia so that further management regarding termination of pregnancy, if required can be done.

\section{CONFLICT OF INTEREST}

Declared none.

\section{ACKNOWLEDGEMENTS}

Declared none.

\section{REFERENCES}

[1] Asif N, Hassan K. Management of thalassemia in Pakistan. J Islamabad Med Dental Coll 2016; 5(4): 152-3.

[2] Ansari SH, Shamsi TS. Thalassaemia prevention programme. Haematol Updates 2010; 23-8.

[3] Iqbal M. Carrier frequency of $\beta$-Thalassaemia in twin-cities of Islamabad and Rawalpindi. J Rawalpindi Med Coll 2012; 16(1): 73-4.

[4] Punjab Thalassaemia Prevention Programme [Internet]. 2012; Available from:https://ptpp.punjab.gov.pk/system/files/Progress\%20Report\%202012.pdf [Accessed Date August 4, $2018]$.
[5] Khan H, Shah F, Khan K. Frequency of B-thalassemia trait among pregnant women in their last trimester with hypochromic microcytic anemia. Pakistan J Public Health 2017; 7(2): 79-81.

[6] Rizwan F, Memon F, Memon A. Frequency of thalassemia trait in pregnant women. Med Channel 2011; 17(1): 56-9.

[7] Ehsan A, DS L. Frequency of carrier rate of $\beta$ Thalassemia trait in females of child bearing age. Biomedica 2017; 33(2): $100-2$.

[8] Qadir M, Amir S. Frequency of $\beta$ thalassemia trait in pregnant anemic patients attending khyber teaching hospital, Peshawar-Pakistan. KMUJ 2017; 9(4): 185-7.

[9] Hafeez M, Aslam M, Ali A, Rashid Y, Jafri H. Regional and ethnic distribution of $\beta$ thalassemia mutations and effect of consanguinity in patients referred for prenatal diagnosis. J Coll Physicians Surg Pak 2007; 17(3): 144-7.

[10] Sinha M, Panigrahi I, Shukla J, Khanna A, Saxena R. Spectrum of anemia in pregnant Indian women and importance of antenatal screening. Indian J Pathol Microbiol 2006; 49(3): 373-5.

[11] Mohanty D, Gorakshakar AC, Colah RB, et al. Interaction of iron deficiency anemia and hemoglobinopathies among college students and pregnant women: A multi center evaluation in India. Hemoglobin 2014; 38(4): 252-7.

DOI: $10.3109 / 03630269.2014 .913517$

[12] Baxi A, Manila K, Kadhi P, Heena B. Carrier screening for $\beta$ thalassemia in pregnant Indian women: Experience at a single center in Madhya Pradesh. Indian J Hematol Blood Transfus 2013; 29(2): 71-4. DOI: 10.1007/s12288-012-0165-8

[13] Wanapirak C, Muninthorn W, Sanguansermsri T, Dhananjayanonda $\mathrm{P}$, Tongsong $\mathrm{T}$. Prevalence of thalassemia in pregnant women at Maharaj Nakorn Chiang Mai Hospital. J Med Assoc Thai 2004; 87(12): 1415-8.

[14] Sarda H, Niveditha SR, Shivlingaiah N. Screening of $\beta$ thalassemia trait among pregnant women with NESTROFT. Thalassemia Reports 2015; 5(1): 1-2. DOI: $10.4081 /$ thal.2015.4430

[15] Ryan K, Bain BJ, Worthington D, et al. Significant haemoglobinopathies: Guidelines for screening and diagnosis. $\mathrm{Br} \mathrm{J}$ Haematol 2010; 149(1): 35-49. DOI: $10.1111 /$ j.1365-2141.2009.08054.x

[16] Faizan-ul-Haq MM, Khan MM, Sajid S, et al. Frequency and awareness of Thalassemia in families with cousin marriages: A study from Karachi, Pakistan. Br J Med Med Res 2017; 21(3): 1-11. DOI: 10.9734/BJMMR/2017/32710 